\title{
Hydrolysis Process Optimization and Functional Characterization of Yak Skin Gelatin Hydrolysates
}

\author{
Hui Yang, ${ }^{1,2,3}$ Yanting Xue, ${ }^{1,2,3}$ Jiaheng Liu, ${ }^{1,2,3}$ Shunyi Song, ${ }^{1,2,3}$ Lei Zhang, ${ }^{1,2,3}$ \\ Qianqian Song, ${ }^{1,2,3}$ Li Tian, ${ }^{1,2,3}$ Xiangyu He, ${ }^{1,2,3}$ Shan He, ${ }^{4}$ and Hongji Zhu $\mathbb{D D}^{1,2,3}$ \\ ${ }^{1}$ Key Laboratory of Systems Bioengineering, Ministry of Education (Tianjin University), Tianjin 300072, China \\ ${ }^{2}$ School of Chemical Engineering and Technology, Tianjin University, Tianjin 300072, China \\ ${ }^{3}$ Collaborative Innovation Center of Chemical Science and Engineering (Tianjin), Tianjin 300072, China \\ ${ }^{4}$ School of Chemistry and Chemical Engineering, Guangzhou University, Guangzhou, China
}

Correspondence should be addressed to Hongji Zhu; zhj@tju.edu.cn

Received 7 May 2019; Revised 25 July 2019; Accepted 13 September 2019; Published 13 October 2019

Guest Editor: SM Mahfuzul Islam

Copyright (c) 2019 Hui Yang et al. This is an open access article distributed under the Creative Commons Attribution License, which permits unrestricted use, distribution, and reproduction in any medium, provided the original work is properly cited.

Yak (Bos grunniens) is an animal mainly living on the Tibetan Plateau. Yak skin is a valuable resource that is wasted in the meat production process. This study aimed to prepare yak skin gelatin hydrolysates (YSGH) from yak skin through enzymatic hydrolysis and investigate functional characterization of YSGH. We showed that trypsin was more effective than neutrase, papain, and pepsin in increasing the degree of hydrolysis (DH) of YSGH. The conditions of enzymatic hydrolysis were optimized using central composite design (CCD) and response surface method (RSM), and the highest DH value of 31.96\% was obtained. We then analyzed the amino acid compositions and molecular weight distribution of peptides in YSGH. The obtained YSGH exhibited certain antioxidant activity and excellent ACE-inhibitory activity $\left(\mathrm{IC}_{50}=0.991 \mathrm{mg} / \mathrm{mL}\right)$. In addition, the solubility (98.79\%), emulsification, and foaming properties of YSGH developed here were also evaluated. With these physicochemical and biological functions, YSGH had potential applications in food, pharmaceuticals, and cosmetics as an ingredient.

\section{Introduction}

Gelatin hydrolysates can be obtained by hydrolysis of gelatin from animal sources such as pigs [1], bovine [2], and fish [3]. It is reported that gelatin hydrolysates have different bioactivities such as antioxidant activities [4,5], ACE-inhibitory activity [6,7], antifreeze activity [8], and antiphotoaging activity [9]. Gelatin hydrolysates have been widely used in the production of pharmaceuticals and foods in the United States and Europe and have the potential for several advanced applications, such as smart drug delivery carriers for cancer therapy [10] and a new type of wound dressing [11]. Compared to gelatin, its hydrolysates are more easily to be absorbed. It was found that oral intake of gelatin hydrolysates has beneficial effects on skin recovery, including supporting wound closure and reducing skin wrinkles [12]. Oral intake of gelatin hydrolysates can also increase bone mass and prevent osteopenia [13]. In these previous studies, the functional properties of gelatin hydrolysates not only depended on the source of gelatin but also the types of enzymes and the enzymolysis conditions [14].

Due to the health concerns about consuming mammal and marine gelatin, there is a market for unpolluted animal gelatin-based products. With a population about 15 million around the world, yaks (Bos grunniens) live in a location where the altitude is about $3000 \mathrm{~m}$ above sea level, mainly along the border of China, India, and Nepal. In China, the population of yaks is the third largest among the cattle. During the evolutionary process, the yak's metabolism has been adapted to harsh living conditions such as high altitude and extreme cold. Living in the unpolluted places made yaks a preferable resource for nutrients and other bioactive products. By-products from different animal resources gained the spotlight with their potentials to be the raw material of bioactive compounds [15-18]. The leftovers from yaks processing, including the head, viscera, skin, and bone, 
should be recycled and converted into value-added products. However, currently the wastes from yaks processing are usually discarded. It is not only causing environmental pollution but is also economically inefficient. Yaks processing wastes could account for up to $30.98 \%$ of the total weight, of which the majority is yak skin [13]. Yak skin consists of moisture $(60 \%-70 \%)$, protein $(30 \%-40 \%)$, fat $(2 \%-4 \%)$, inorganic salt $(0.5 \%-1.5 \%)$, and carbohydrates. The yak skin gelatin contains eighteen different amino acids, among which seven are essential amino acids and two are trace elements [19]. Therefore, yak skin can be an ideal raw material to produce gelatin hydrolysates by enzymatic hydrolysis. Previous study illustrated the possibility of extracting collagen and gelatin from meat by-products [20]. However, to date, little investigation has been done regarding optimal enzymatic hydrolysis process and the characterization of gelatin hydrolysates derived from yak skin.

Therefore, the objectives of this study were to optimize the bioprocess of enzymatic hydrolysis to produce gelatin hydrolysates from yak skin by using commercial protease and characterize the functionalities of the obtained gelatin hydrolysates.

\section{Materials and Methods}

2.1. Material. Yak skin was obtained from the yak market (Qinghai, China). Proteases of trypsin, neutrase, papain, pepsin, reagents of 1,1-diphenyl-2-picrylhydrazyl (DPPH), reduced L-glutathione (GSH), hydroxyproline, and the ACE synthetic substrate hippuryl-L-histidyl-L-leucine (HHL) were all purchased from Sigma-Aldrich (Shanghai, China). All reagents used in this study were of analytical grade.

2.2. Pretreatment of Yak Skin. Yak skin was soaked in water, and its impurities and hair were cleaned and removed, then chopped into $0.5 \times 0.5 \mathrm{~cm}^{2}$ and stored at $-20^{\circ} \mathrm{C}$. The pieces of skin were mixed with $\mathrm{n}$-butyl alcohol solution $(1: 10, \mathrm{w} / \mathrm{v})$ at a ratio of solid to solution $1: 20(\mathrm{w} / \mathrm{v})$ to remove fat and noncollagen protein. The mixture was stirred for $24 \mathrm{~h}$ at $4^{\circ} \mathrm{C}$, then washed with distilled water until neutral $\mathrm{pH}$. Defatted residues were treated with $0.1 \mathrm{M}$ sodium hydroxide solution at a sample/alkaline solution ratio of $1: 30(\mathrm{w} / \mathrm{v})$ with stirring for another $36 \mathrm{~h}$ at $4^{\circ} \mathrm{C}$. Finally, the deproteinised skin was rinsed with water until it reached a $\mathrm{pH}$ of 7.0.

2.3. Extraction of Gelatin. The pretreated yak skin was rinsed with $0.2 \% \mathrm{HCl}(\mathrm{w} / \mathrm{v})$ solution $(1: 8, \mathrm{w} / \mathrm{v})$ for $4 \mathrm{~h}$ at room temperature followed by rinsing with water until it reached a $\mathrm{pH}$ of 7.0. The residues were then soaked in distilled water $\left(85^{\circ} \mathrm{C}\right)$ until the skin was completely dissolved in the solution. The supernatant was collected by centrifugation at $6580 \times g$ for $15 \mathrm{~min}$ at room temperature, then concentrated by rotary evaporator and lyophilized by a freeze drier (Alpha1-2, Christ, Germany). The freeze-dried powder, named was gelatin, was stored in a desiccator at room temperature until use. The gelatin yield was calculated by the ratio of freeze-dried powder to the raw material. Crude protein, lipid, and ash contents in the extracted gelatin were analyzed according to national text standard of China (GB/T 5009.5-2010, GB/T 5009.6-2003, and GB/T 5009.4-2010).

2.4. Enzymatic Hydrolysis. The type of enzyme plays an important role to the quality of DH. In order to identify the most efficient enzyme to produce gelatin hydrolysates from yak skin, enzymatic hydrolysis was performed using four proteases individually: neutrase $\left(\mathrm{pH} 7.0,45^{\circ} \mathrm{C}\right)$, pepsin $(\mathrm{pH}$ $\left.2.0,37^{\circ} \mathrm{C}\right)$, trypsin $\left(\mathrm{pH} 7.5,50^{\circ} \mathrm{C}\right)$, and papain $\left(\mathrm{pH} 6.2,25^{\circ} \mathrm{C}\right)$ at each optimum condition with protease concentration of $2000 \mathrm{U} / \mathrm{g}$. The optimum $\mathrm{pH}$ and temperature conditions for each enzyme are shown in the brackets above. After hydrolysis were processed with the selected time, the resulted hydrolysates solution was inactivated by boiling in water for $15 \mathrm{~min}$, followed by centrifugation $(6580 \times \mathrm{g}, 15 \mathrm{~min})$. The supernatants were collected to measure the $\mathrm{DH}$ and then lyophilized by a freeze drier (Alphal-2, Christ, Germany). The freeze-dried powder, which was named as gelatin hydrolysates, was stored in a desiccator at room temperature until use. For each enzyme, the gelatin hydrolysates with the highest DH were chosen to measure their DPPH scavenging activity.

2.5. Degree of Hydrolysis (DH). DH was determined by the ratio of the number of cleaved peptide bonds to the total number of bonds per unit mass weight. The degree of gelatin hydrolysis was evaluated according to the trinitrobenzene sulfonic acid (TNBS) method [21]. All determinations were made in duplicate. DH was defined as follows:

$$
\operatorname{DH}(\%)=\frac{\left(L_{\mathrm{S}}-L_{0}\right)}{\left(L_{\max }-L_{0}\right)} \times 100,
$$

where $L_{\mathrm{s}}$ is the content of free $\alpha$-amino groups in the hydrolysate, $L_{0}$ is the content of free $\alpha$-amino groups in gelatin, and $L_{\max }$ is the content of $\alpha$-amino in substrate reacted with $6 \mathrm{~mol} / \mathrm{L} \mathrm{HCL}$ for $24 \mathrm{~h}$ at $100^{\circ} \mathrm{C}$.

\subsection{Experiment Design and Data Analysis}

2.6.1. Fractional Factorial Designs of Experiments. Factorial design was carried out to screen 5 variable factors $(\mathrm{pH}$, temperature, ratio of enzyme to substrate $(\mathrm{E} / \mathrm{S})$, substrate concentration, and the hydrolysis time). The aim of the factorial design was to identify relatively important variables and interactions among independent variables. The regression analysis of the variables was performed using SPSS software version 20.0 (IBM, USA).

2.6.2. Central Composite Design (CCD) and Response Surface Methodology (RSM) of Experiments. The enzymatic hydrolysis conditions were optimized by RSM based on single factor experiments and factorial designs. A CCD design with 3-factor and 3-level was applied to explore the effect of the independent variables on DH. Analysis of variance (ANOVA) was estimated with Design Expert software (Version 8.0.6, State-Ease Inc. Minneapolis, USA). All the 
experiments were conducted in triplicate, and the average values were recorded as the response values with deviations.

\subsection{Analysis of Physiochemical Properties}

2.7.1. Amino Acid Analysis. The gelatin hydrolysates $(10 \mathrm{mg})$ were hydrolysed in $5 \mathrm{ml}$ of $6 \mathrm{M} \mathrm{HCl}$ at $110^{\circ} \mathrm{C}$ in a set of time in a vacuum and then neutralized with $3.5 \mathrm{M} \mathrm{NaOH}$. The solution was diluted with $0.2 \mathrm{M}$ citrate buffer $(\mathrm{pH} 2.2)$ after neutralization. Finally, the amino acids of the gelatin hydrolysates in the solution were identified and quantified by the automatic amino acid analyzer (Biochrom 30+, Pharmacia Biotech, UK).

2.7.2. Determination of Solubility. The nitrogen solubility index (NSI) was used to show the solubility of protein hydrolysates. In brief, gelatin hydrolysates $(0.5 \mathrm{~g})$ were dissolved in $50 \mathrm{ml}$ of $0.1 \mathrm{M} \mathrm{NaCl}$ at $\mathrm{pH} 7.0$ followed by centrifugation $(640 \times g, 30 \mathrm{~min})$. The nitrogen content in the supernatant was analyzed for nitrogen by the macro-Kjeldahl method [22]. NSI was calculated as follows:

$$
\mathrm{NSI}(\%)=\frac{A}{B} \times 100 \text {, }
$$

$A$ is the nitrogen content of the supernatant and $B$ is the total nitrogen content of the sample.

2.7.3. Emulsifying Properties. The emulsification activities (EA) and emulsification stability (ES) were determined as described by Shahidi et al. [23]. The gelatin hydrolysate sample (0.5 g) was dissolved in $25 \mathrm{ml}$ distilled water ( $\mathrm{pH} 7$ ). Adding $25 \mathrm{ml}$ of oil into the prepared gelatin hydrolysate solution, the mixture was transferred into $50 \mathrm{ml}$ cylinders and homogenized at a speed of $10280 \times g$ for $2 \mathrm{~min}$ at room temperature. The obtained emulsion was divided into two portions. One was centrifuged at $230 \times g$ for $5 \mathrm{~min}$. EA was calculated by the following equation:

$$
\mathrm{EA}(\%)=\frac{V_{1}}{V_{0}} \times 100,
$$

where $V_{1}$ is the height of the emulsion layer and $V_{0}$ is the height of the mixture solution.

The other portion was incubated in water at $50^{\circ} \mathrm{C}$, and the volume of the emulsion phase was recorded every hour. ES was calculated according to the following equation:

$$
\mathrm{ES}(\%)=\frac{V_{2}}{V_{3}} \times 100,
$$

where $V_{2}$ is the total volume of the emulsion every hour and $V_{3}$ is the initial volume of the emulsion.

2.7.4. Foaming Properties. Foam expansion (FA) and foam stability (FS) were determined according to the method described by Shahidi et al. [23]. In brief, $0.5 \mathrm{~g}$ dried gelatin hydrolysates were dissolved in $50 \mathrm{ml}$ distilled water, and then homogenized at $10280 \times g$ for $2 \mathrm{~min}$ at room temperature. The sample stood for $0,1,3$, and $10 \mathrm{~min}$. Meanwhile, the volume of the solution was recorded. FA and FS were calculated by the following equations:

$$
\begin{aligned}
& \mathrm{FA}(\%)=\frac{A-B}{B} \times 100, \\
& \mathrm{FS}(\%)=\frac{A_{\mathrm{t}}-B}{A-B} \times 100,
\end{aligned}
$$

where $A$ is the total volume after whipping, $B$ is the original volume before whipping, and $A_{\mathrm{t}}$ is the total volume after standing for different lengths of time $(0,1,3$, and $10 \mathrm{~min})$.

All measurements were carried out in triplicate.

\subsection{Analysis of Biological Properties}

\subsubsection{Determination of Antioxidant Activities}

(1) Determination of DPPH Scavenging Activity. The DPPH radical scavenging assay was performed according to the method reported by Nazeer et al. [24] with some modifications. The sample was mixed with ethanolic DPPH $(0.1 \mathrm{mmol} / \mathrm{L})$ at volumetric ratio of $1: 1$. The mixture was left in the dark for $30 \mathrm{~min}$, and the absorbance was measured at a wavelength of $517 \mathrm{~nm}$. The DPPH was calculated using the following equation:

$$
\begin{aligned}
& \text { DPPH radical scavenging activity (\%) } \\
& \qquad=\frac{A_{\text {control }}+A_{\text {blank }}-A_{\text {sample }}}{A_{\text {control }}} \times 100,
\end{aligned}
$$

where $A_{\text {control }}$ is the absorbance of the control (distilled water instead of sample) and $A_{\text {blank }}$ is the absorbance of the sample with ethanol instead of DPPH.

(2) Determination of Superoxide Anion Radical Scavenging Activity. Superoxide anion scavenging activity was measured using the methods described by Xie et al. [25] with some modifications. $0.2 \mathrm{~mL}$ sample, $4 \mathrm{~mL}$ distilled water, and $4.5 \mathrm{~mL}$ Tris- $\mathrm{HCl}$ buffer $(0.05 \mathrm{~mol} / \mathrm{L} ; \mathrm{pH} 8.2)$ were mixed together and incubated for $10 \mathrm{~min}$ at $25^{\circ} \mathrm{C} .0 .3 \mathrm{~mL}$ pyrogallol was added after incubation. The absorbance was measured at a wavelength of $299 \mathrm{~nm}$ every $30 \mathrm{~s}$ for $5 \mathrm{~min}$. The superoxide radical scavenging activity was calculated using the following equation:

$$
\text { scavenging anion activity }(\%)=\left(1-\frac{A_{\mathrm{i}}}{A_{0}}\right) \times 100,
$$

where $A_{0}$ is the absorbance of the control (distilled water instead of sample) and $A_{\mathrm{i}}$ is the absorbance of the sample.

(3) Hydroxyl Radical Scavenging Activity. The scavenging capacity for hydroxyl radicals was measured according to the modified method described by de Avellar et al. [26]. The mixture, containing $0.2 \mathrm{ml} o$-phenanthroline $(0.75 \mathrm{mM})$, $0.4 \mathrm{ml}$ of $0.2 \mathrm{M}$ phosphate buffer ( $\mathrm{pH} 7.4), 0.2 \mathrm{ml}$ distilled water, and $0.2 \mathrm{ml}$ of $0.75 \mathrm{mM} \mathrm{FeSO}_{4}$, was reacted with $0.2 \mathrm{ml}$ $\mathrm{H}_{2} \mathrm{O}_{2}\left(0.1 \%\right.$, v/v) and a $0.4 \mathrm{ml} \mathrm{sample}$ at $37^{\circ} \mathrm{C}$ for $60 \mathrm{~min}$. The absorbance of the resulting solution was measured at a 
wavelength of $536 \mathrm{~nm}$. The hydroxyl radical scavenging activity was calculated using the following equation:

$$
\text { hydroxyl radical scavenging activity }(\%)=\frac{A_{\mathrm{S}}-A_{\mathrm{P}}}{A_{\mathrm{B}}-A_{\mathrm{P}}} \times 100 \text {, }
$$

where $A_{\mathrm{S}}$ is the absorbance of the control (distilled water instead of sample), $A_{\mathrm{B}}$ is the absorbance of the samples (distilled water instead of $\mathrm{H}_{2} \mathrm{O}_{2}$ ), and $A_{\mathrm{P}}$ is the absorbance of the samples.

\subsubsection{Angiotensin-Converting Enzyme (ACE) Inhibitory} Assay. The ACE-inhibitory effect was determined by the spectrophotometric method with some modifications [27]. A sample solution $(50 \mu \mathrm{l})$ and $150 \mu \mathrm{l}$ of $2.5 \mathrm{mM}$ ACE synthetic substrate HHL reacted with $50 \mu \mathrm{l} \mathrm{ACE}(25 \mathrm{mU} / \mathrm{ml})$ at $37^{\circ} \mathrm{C}$ for $1 \mathrm{~h}$. The reaction was stopped by adding $1 \mathrm{M} \mathrm{HCl}$ $(150 \mu \mathrm{l})$. The resulting hippuric acid was extracted by adding $1.5 \mathrm{ml}$ ethyl acetate and followed by centrifugation $(2570 \times \mathrm{g}$, $15 \mathrm{~min}$ ). The hippuric acid was dissolved in $3 \mathrm{ml}$ distilled water, and the absorbance was measured at a wavelength of $228 \mathrm{~nm}$ using a TU-1901 UV-spectrophotometer (Beijing, China). The ACE-inhibitory effect was calculated as follows:

$$
\operatorname{ACE}-\text { inhibitory activity }(\%)=\frac{A_{\mathrm{a}}-A_{\mathrm{b}}}{A_{\mathrm{a}}-A_{\mathrm{c}}} \times 100,
$$

where $A_{\mathrm{a}}$ is the absorbance of the control, $A_{\mathrm{b}}$ is the absorbance of the sample, and $A_{\mathrm{c}}$ is the absorbance of the blank without ACE or the sample.

2.9. Statistical Analysis. All the experiments were carried out in triplicate. The results were recorded as means \pm standard deviation and subjected to one-way analysis of variance (ANOVA) using SPSS software version 20.0 (IBM, USA). The significance was evaluated statistically by the $F$ value at a probability $(P)$ below 0.05 .

\section{Results and Discussion}

3.1. Preparation of Yak Skin Gelatin. The composition of gelatin was related to the type of animal and the environment in which the animal grows. The flowchart of technological process was shown in Figure 1. The obtained gelatin contained protein (96.58\%), lipid (1.27\%), and ash $(1.90 \%)$. The gelatin yield reached $52.97 \%$, which is much higher than the reported extraction rates of many other animal gelatins [28-30]. The reason might be that yak skin contained more proteins and less lipids since yaks live in high altitudes with extremely cold climates [31]. Thus, the higher gelatin yield ensured the feasibility of its use in preparing gelatin hydrolysates.

3.2. Screening of Efficient Enzyme. DH value was generally used to evaluate the hydrolysis effectiveness of macromolecule proteins [32]. A higher DH value could represent the more numbers of short-chain peptides in the hydrolysates. Different proteases might exhibit different catalytic activity on yak skin gelatin due to their different specific catalytic centers. Therefore, four types of proteases including trypsin, neutrase, papain, and pepsin were applied in this study. The results of enzymatic hydrolysis of yak skin gelatin using these enzymes with an activity of $2000 \mathrm{U} / \mathrm{g}$ for $7 \mathrm{~h}$, respectively, were shown in Figure 2. Based on DH value, the order of efficiency of the four enzymes was found to be the following: trypsin $>$ neutrase $>$ papain $>$ pepsin. The highest $\mathrm{DH}$ value of $20.43 \%$ was attained with trypsin at $4 \mathrm{~h}$. Trypsin, a serine endopeptidase, acts on the peptide linkage between the carboxyl groups of lysine and arginine. Its effectiveness has also been verified in enzymatic hydrolysis of fish skin, such as salmon [33] and flatfish [5].

3.3. Optimization of Enzymatic Parameter. The variables and coded levels were presented in Table S1. The experiment design and results were shown in Table S2. DH ranged from $8.47 \%$ to $26.48 \%$ with different levels of factors. This obviously indicated that the variables of digestion could directly affect $\mathrm{DH}$. The $F$ value was 4.261 , and the $p$ value was 0.053 (Table S3). According to the regression analysis of variables shown in Table S4, the factors of temperature, E/S, and substrate concentration were found to have great effects on the hydrolysis reaction, among which substrate concentration was the most significant factor $(p=0.006)$. Therefore, these three factors were chosen for response surface analysis.

Based on factorial analysis, the enzymatic parameters were optimized by RSM. The CCD with 3-factor and 3-level was utilized to explore the effect of independent variables on DH (Table S5). The analysis of the developed quadratic polynomial model for variables was shown in Table S6. The value of coefficient determination $R^{2}$ was 0.8562 , higher than 0.85 . This indicated that the model was accurate and acceptable. According to the regression analysis, the variability in the response could be explained by the second-order polynomial model given below:

$$
\mathrm{DH}=30.63+1.49 C-1.98 D-1.42 B^{2}-1.07 C^{2}-2.07 D^{2} .
$$

The equation was significant with a $p$ value less than 0.01 (Table S6). DH of hydrolysates was primarily determined by the linear and quadratic terms of the temperature, $\mathrm{E} / \mathrm{S}$, and substrate concentration. Among these factors, the most significant one was substrate concentration $(p<0.001)$.

The three-dimensional (3D) response surface plots (Figure 3) explained the results of statistical and mathematical analysis of the effects of temperature, E/S, and substrate concentration on DH. A quadratic relation was apparent between DH and the three variables. The value of $\mathrm{DH}$, predicted by the Design Expert software program, reached its maximum by a combination of coded levels at $0.26(B), 0.70(C)$ and $-0.48(D)$. The corresponding variables were temperature of $51.32^{\circ} \mathrm{C}, \mathrm{E} / \mathrm{S}$ of $3695.45(\mathrm{U} / \mathrm{g})$ and substrate concentration of $6.3 \%(\mathrm{w} / \mathrm{w})$, with the predicted response of $\mathrm{DH}$ being $31.72 \%$.

In order to validate the above prediction, experiments were carried out using the predicted variables (shown 


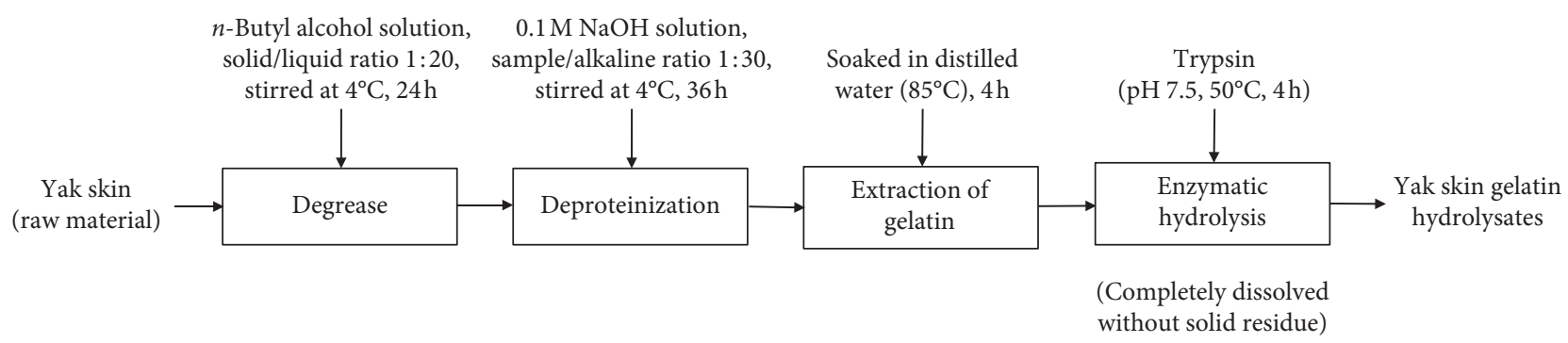

FIGURE 1: The technological process diagram of preparation of yak skin gelatin hydrolysates.

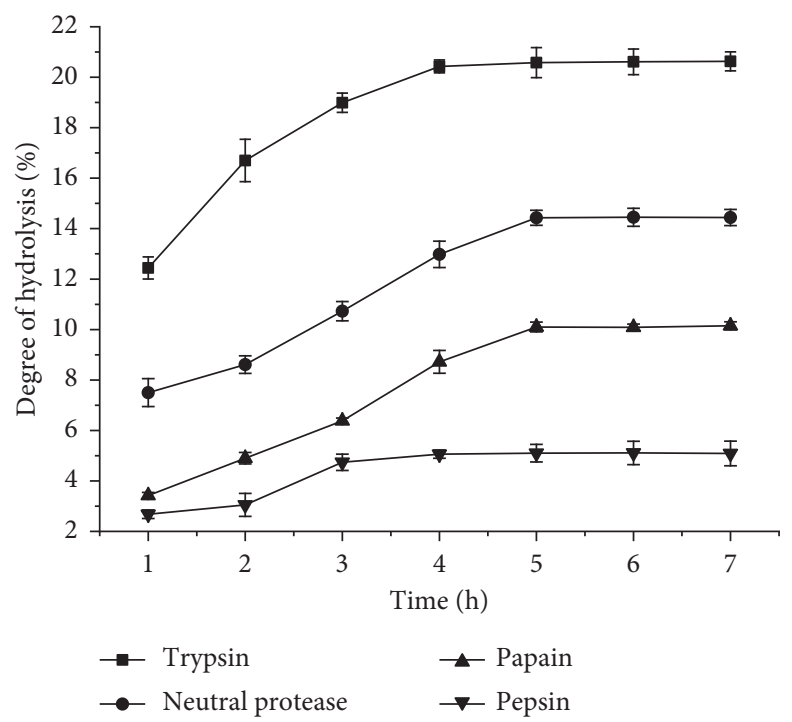

FIGURE 2: The degree of hydrolysis (DH) of yak skin gelatin hydrolysates by different enzymes at $2000 \mathrm{U} / \mathrm{g}$ and hydrolysis times. Results are displayed as average \pm standard deviations from three replications.

above), with slight adjustments: temperature of $51^{\circ} \mathrm{C}, \mathrm{E} / \mathrm{S}$ of $3695(\mathrm{U} / \mathrm{g})$, and substrate concentration of $6.3 \%(\mathrm{w} / \mathrm{w})$. The $\mathrm{DH}$ of the resulted gelatin hydrolysates reached $31.96 \%$. Compared with the predicted number of $31.72 \%$, relative error was only $0.75 \%$. This experiment validated the accuracy of the experimental design in this study. And the DH increased from $20.43 \%$ to $31.96 \%$ under optimized conditions.

\subsection{Amino Acid Composition and Molecular Weight Distri-} bution of Peptides in YSGH. Amino acid composition of the protein hydrolysates were influenced by protein source, type of protease, and hydrolysis conditions, and played an important role in the physiochemical and biological properties of hydrolysates. Thus, we detected the amino acid composition of the YSGH. As shown in Table 1, YSGH contained a considerable amount of glycine $(19.87 \pm 0.24 \%)$, proline $(12.87 \pm 0.40 \%)$, glutamate $(10.34 \pm 0.11 \%)$, hydroxyproline $(7.08 \pm 0.56 \%)$, and alanine $(6.50 \pm 0.17 \%)$. These amino acids have been proved to be essential for the functions of many bioactive peptides, such as antioxidant activity [3537], ACE-inhibitory activity [38], and antimicrobial activity [39]. Furthermore, large amounts of hydrophilic amino acids $(65.18 \%)$, as well as the high DH of YSGH (31.96\%), ensured the solubility of YSGH (98.79\%). Additionally, flavor amino acids such as aspartate and glutamate participated in flavor development of the products [40]. Thus, YSGH is expected to have excellent biological properties and have potential to be used as source of functional peptides in food industry.

Meanwhile, we analyzed the molecular weights of peptides in YSGH by GPC (gel permeation chromatography). The molecular weights of the peptides were mainly distributed in the range of 400 to $3500 \mathrm{Da}$. The peptides in the molecular weight range of $1000-2236 \mathrm{Da}$ accounted for the largest proportion of components (Table 2). Furthermore, many researchers have found that the peptides in this range of molecular weight showed excellent biological activities, such as antioxidant activity [41] and ACE-inhibitory activity [7].

3.5. Emulsifying and Foaming Properties. As shown in Table S7, YSGH exhibited a certain degree of emulsifying activity $(47.6 \pm 0.7 \%)$ and emulsion stability ranging from $91.7 \pm 0.5 \%$ to $79.1 \pm 0.3 \%$. ES decreased slightly within $5 \mathrm{~h}$. The hydrolysates with short-chain peptides showed acceptable solubility and various hydrophobic groups. It is assumed the amphiphilic polymers with hydrophobic and 


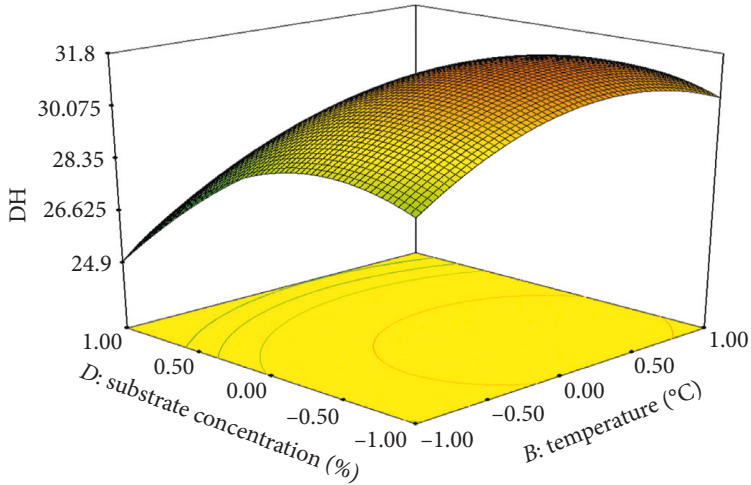

(a)

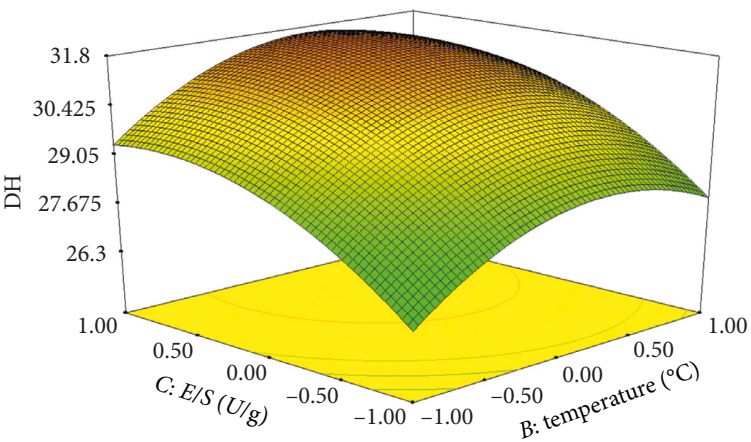

(c)

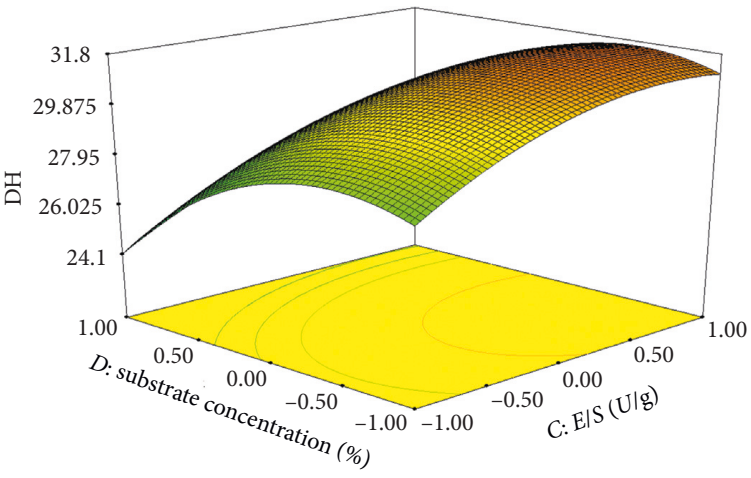

(e)

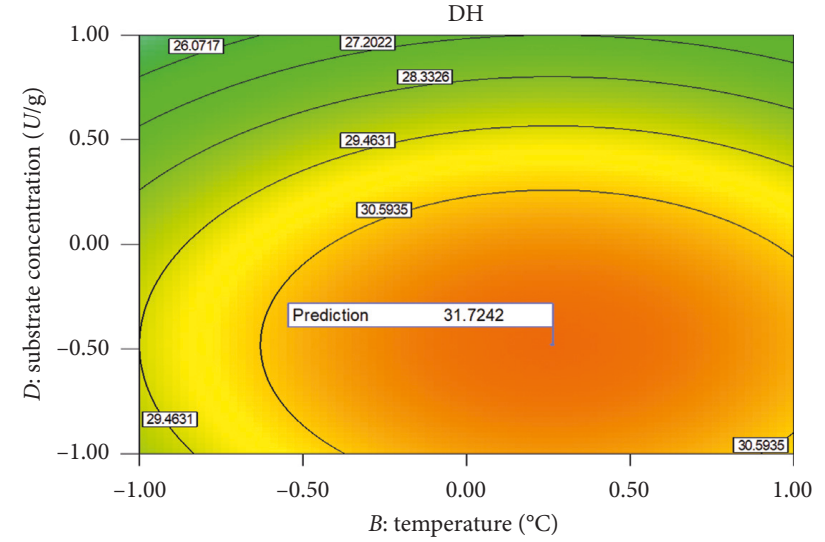

(b)

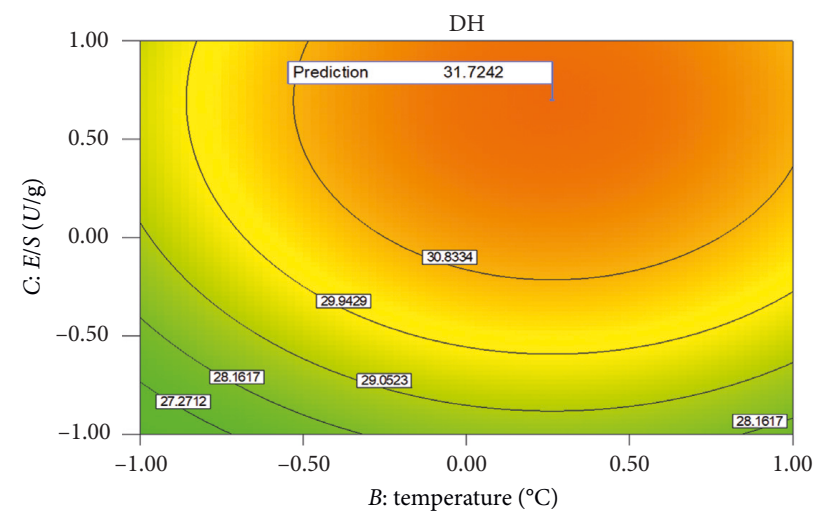

(d)

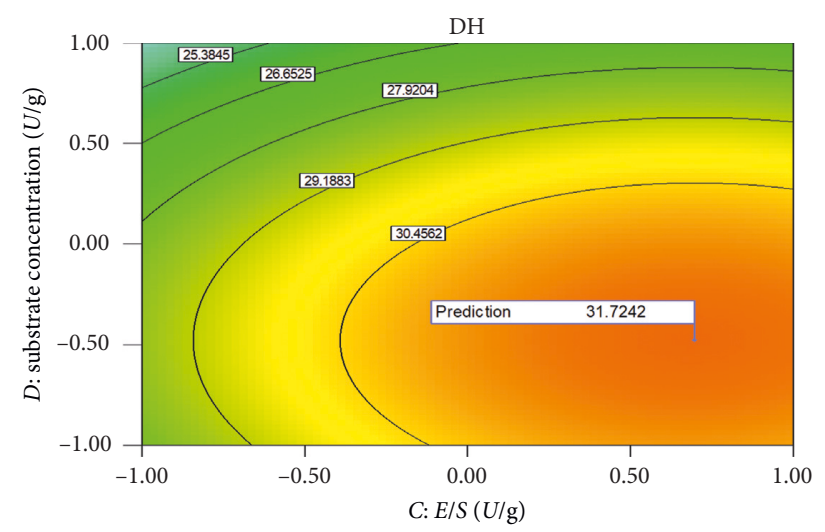

(f)

FIgURE 3: Response surface three-dimensional map and contour plots of the degree of hydrolysis.

hydrophilic moieties tended to protect oil in water with homogenization and film formation. Hence, the hydrolysis process can increase the hydrophilic groups and also expose the hydrophobic groups at the surface. This phenomenon leads to the formation of amphipathic complexes to reduce surface tension and stabilize the surface film [42]. On the other hand, the high degree of solubility contribute to the rapidly hydrolysates diffuse and allow absorption at the interface. Moreover, trypsin treatment contributes to the emulsifying properties $[43,44]$. Due to its outstanding emulsifying properties, YSGH could be used as an emulsifier in the food industry.

Foaming property is an important functionality of collagen peptides and often used in food products. The foam capacity (FC) and foam stability (FS) of YSGH is presented in Table S8. The stability drops rapidly in the first ten minutes but becomes more stable with the time increase. For foam formation, the hydrolysates should be soluble in liquid and be capable of rapid migration and orientation to form an interfacial film that can decrease the surface tension. Since 
TABLE 1: Amino acid composition of yak skin gelatin hydrolysates and porcine skin gelatin hydrolysates.

\begin{tabular}{lc}
\hline Amino acid & $\begin{array}{c}\text { Composition/100 g gelatin } \\
\text { hydrolysates of yak skin [34]. }\end{array}$ \\
\hline Aspartate & $4.90 \pm 0.38$ \\
Threonine & $1.35 \pm 0.16$ \\
Serine & $2.32 \pm 0.31$ \\
Glutamic acid & $10.34 \pm 0.11$ \\
Proline & $12.87 \pm 0.40$ \\
Glycine & $19.88 \pm 0.24$ \\
Alanine & $6.50 \pm 0.17$ \\
Cysteine & $0.46 \pm 0.02$ \\
Valine & $1.86 \pm 0.07$ \\
Methionine & $0.98 \pm 0.04$ \\
Isoleucine & $1.08 \pm 0.09$ \\
Leucine & $2.40 \pm 0.19$ \\
Tyrosine & $1.02 \pm 0.02$ \\
Phenylalanine & $2.34 \pm 0.25$ \\
Histidine & $0.63 \pm 0.03$ \\
Lysine & $3.02 \pm 0.32$ \\
Arginine & $5.73 \pm 0.23$ \\
Hydroxyproline & $7.08 \pm 0.56$ \\
Hydrophilic amino acid & $55.25 \pm 1.56(65.18 \%)$ \\
Hydrophobic amino acid & $29.51 \pm 0.48(34.82 \%)$ \\
Total & $84.76 \pm 2.02$
\end{tabular}

Values are given as means \pm standard deviations from triplicate determination.

TABLE 2: The molecular weight distribution of yak skin gelatin hydrolysates.

\begin{tabular}{lc}
\hline Molecular weight distribution (MW) & Weight percentage $(w \%)$ \\
\hline $198-416$ & 4.96 \\
$418-996$ & 22.43 \\
$1000-2236$ & 42.46 \\
$2245-3502$ & 20.11 \\
$3516-5442$ & 6.95 \\
$5465-16640$ & 3.09 \\
\hline
\end{tabular}

simultaneous dehydration and hydrophobic portions of the hydrolysates are favorable for thermodynamics, the spontaneous adsorption of hydrolysates from solution to the air/ aqueous interface is a major driving force for foaming formation [45]. The hydrolysis of gelatin can shorten the amino acid chain and reduce the surface tension resulting in parcels of gas bubbles and to improve foam stability. YSGH, a hydrolysis product with many hydrophobic regions, exhibited the certain degree of foaming properties. Surface hydrophobicity had been reported to have effective relations with foaming properties [46].

\subsection{Biological Properties of YSGH}

3.6.1. Antioxidant Activities. Antioxidants have important roles both in food and in human body by counteracting oxidation processes. Recently, an increasing number of researches focused on exploring the antioxidants content of foods, especially of the animal by-product wastes [47]. In this study, DPPH scavenging activity, superoxide anion radical scavenging activity, and hydroxyl radical scavenging activity were evaluated, respectively, and the results were compared with reduced glutathione (GSH), which is a commercial antioxidant. As shown in Figure 4(a), the DPPH scavenging activity of YSGH increased linearly with the hydrolysates concentration. When the concentration of YSGH was $5 \mathrm{mg} / \mathrm{ml}$, the DPPH-scavenging activity of YSGH reached $59.79 \%$, higher than that of flatfish skin hydrolysates [5] and Pseudosciaena crocea protein hydrolysates [48]. As expected, the DPPH-scavenging activity of YSGH is much higher than that of porcine skin gelatin hydrolysates as well (19.25\%) [34]. These results were in accordance with previous studies, which showed that hydrolysates and peptides isolated from bovine skin gelatin owned antioxidant properties [49]. In addition, many researches demonstrated that the peptides with lower molecular weight exhibits higher antioxidant activity. It is well known that the types of enzymes and enzymatic hydrolysis conditions could influence the molecular weight distribution and functional properties of the hydrolysates [14]. Thus, the trypsin hydrolysates showed the highest DPPH scavenging activity, which positively correlated with the high DH (Table 3).

Superoxide anion radical, as a main radical resource in vivo, can produce hydrogen peroxide and hydroxyl radicals that can lead to cytotoxicity. Figure 4(b) showed that the superoxide anion radical scavenging activity of YSGH was maintained at $28.19 \%$ while the concentration ranged from $1 \mathrm{mg} / \mathrm{ml}$ to $5 \mathrm{mg} / \mathrm{ml}$, indicating that YSGH exhibited a certain degree of superoxide anion radical scavenging activity.

Scavenging of hydroxyl radicals plays an indispensable role in the body. The hydroxyl radical scavenging activity of YSGH was approximately in direct proportion to the concentration of YSGH and reached its maximum $(53.28 \pm 1.46 \%)$ at $5 \mathrm{mg} / \mathrm{ml}$ (Figure $4(\mathrm{c}))(p<0.05)$. It was reported that antioxidant properties of hydrolysates depend on amino acid composition, structure, and hydrophobicity. Above all, YSGH exhibited great antioxidant activities against DPPH, superoxide, and hydroxyl radicals, indicating that YSGH has great potential in being an antioxidant against oxidative damage.

3.6.2. ACE-Inhibitory Activity. The ACE-inhibitory activity acts as a major role in the control of blood pressure. Usually, ACE-inhibitory peptides have been reported to be short peptides with Pro residues. It has been reported that the presence of Leu residues has a positive correlation with both antioxidant and ACE-inhibitory activities [4]. The ACEinhibitory activity of YSGH increased with the increase of concentration from 0 to $4 \mathrm{mg} / \mathrm{ml}$ (Figure 5). The ACE-inhibitory activity of YSGH shows a higher ACE-inhibitory activity $\left(\mathrm{IC}_{50}=0.991 \mathrm{mg} / \mathrm{ml}\right)$ than that of bovine skin gelatin hydrolysates treated with trypsin $\left(\mathrm{IC}_{50}=1.044 \mathrm{mg} / \mathrm{ml}\right)$ [50]. YSGH exhibited great biological properties because it had a high DH by trypsin treatment, thus the molecular weight distribution of caused peptides become broader with more small peptides relating to the ACE-inhibitory activity. Also, a high positive correlation was found between ACE-inhibitory 

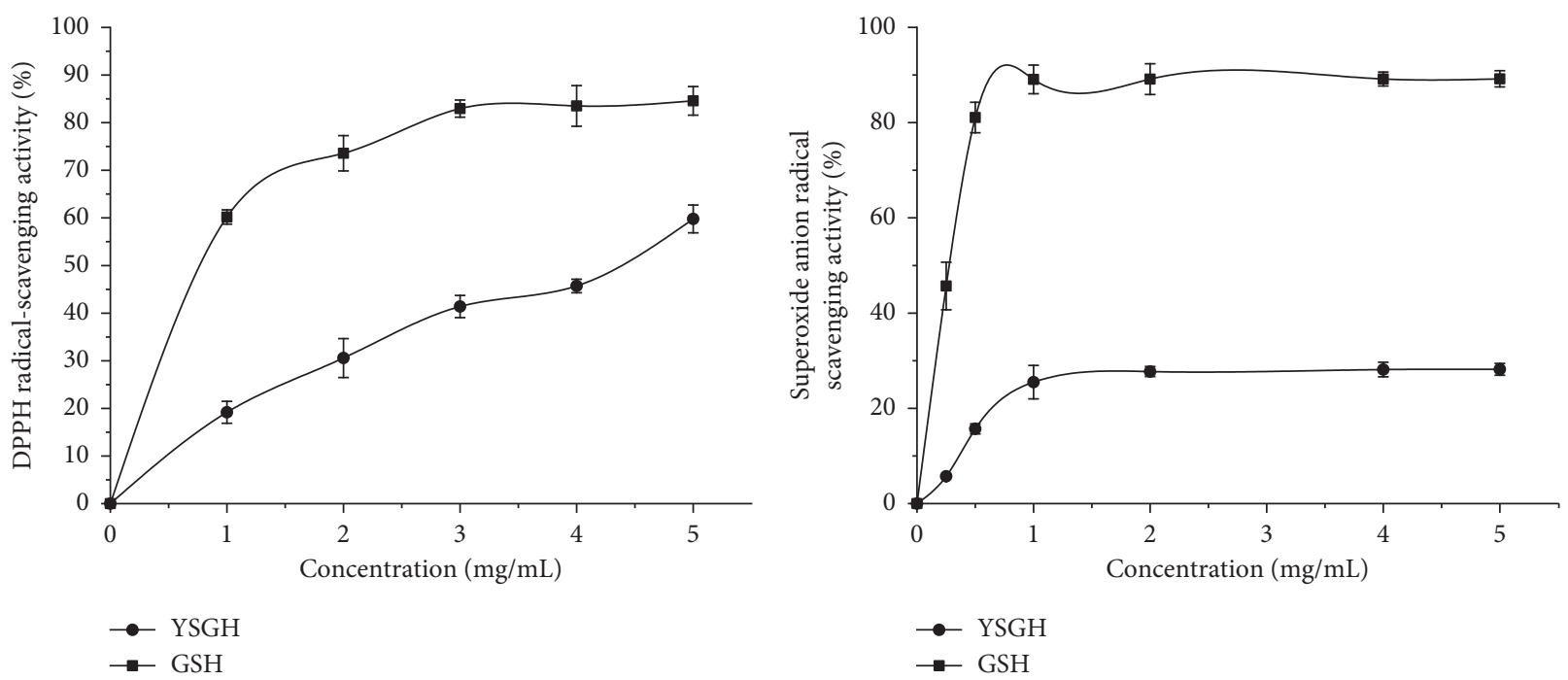

(a)

(b)

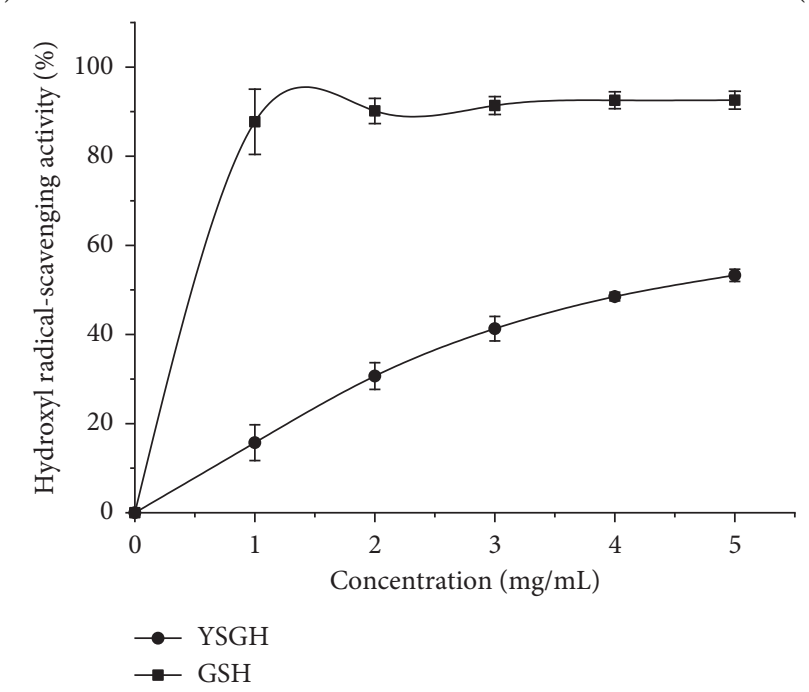

(c)

FIGURE 4: Scavenging effect of yak skin gelatin hydrolysates (YSGH) and reduced L-glutathione (GSH). (a) Effect on DPPH free radicals; (b) effect on superoxide anion radicals; (c) effect on hydroxyl free radicals. Data displayed as average \pm standard deviations from three replications.

TABLE 3: DPPH scavenging activity of yak skin gelatin hydrolysates by four-enzyme treatment under each optimum conditions.

\begin{tabular}{lcccc}
\hline & Trypsin & Neutrase & Papain & Pepsin \\
\hline DPPH scavenging activity (\%) & $53.22 \pm 0.25$ & $45.75 \pm 0.34$ & $39.55 \pm 0.12$ & $32.94 \pm 0.09$ \\
\hline
\end{tabular}

Values are given as mean \pm SD from triplicate determinations.

and DPPH radical scavenging activities in Alcalase hydrolysates of soya protein [49].

\section{Conclusion}

This study developed an economic and efficient process for preparing bioactive YSGH from yak skin through enzymatic hydrolysis. In general, the bioavailability of gelatin products is influenced by the molecular weight distribution and amino acid composition, which was associated with the $\mathrm{DH}$ of the hydrolysates. Trypsin hydrolysates showed the highest $\mathrm{DH}$ and DPPH scavenging activity compared to those attained by neutrase, papain, and pepsin.

The optimum conditions for preparing YSGH by trypsin were as follows: temperature of $51^{\circ} \mathrm{C}, \mathrm{E} / \mathrm{S}$ of $3695(\mathrm{U} / \mathrm{g})$, and substrate concentration of $6.3 \%(\mathrm{w} / \mathrm{w})$. Under such conditions, the maximum $\mathrm{DH}$ value of $31.96 \%$ was attained, which agreed well with that predicted by the RSM model (31.72\%). The obtained YSGH contained large amounts of hydrophilic amino acids (65.18\%), and the peptides in the molecular 


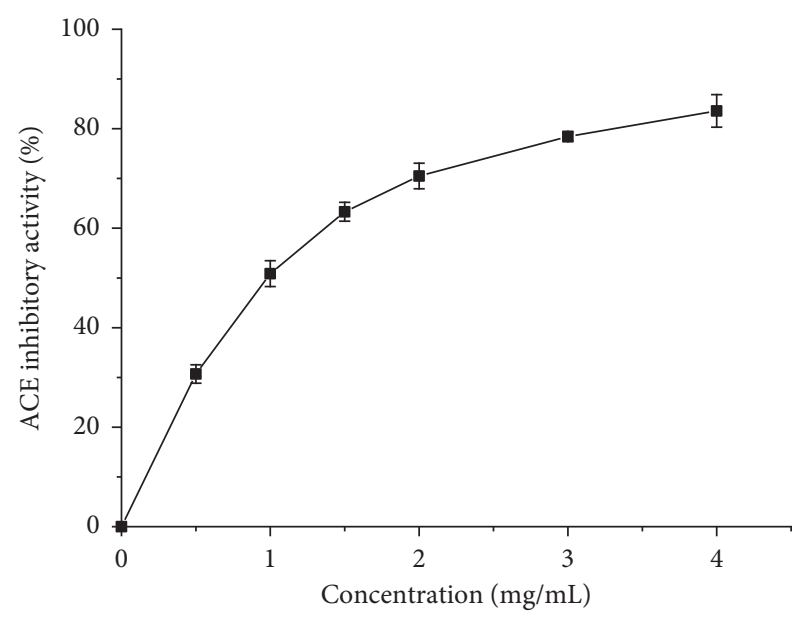

Figure 5: Effect on ACE-inhibitory activity. Data displayed as average \pm standard deviations from three replications.

weight range of 1000-2236 $\mathrm{Da}$ accounted for the largest proportion of components. YSGH exhibited good results for the properties of solubility $(98.79 \%)$, emulsifying and foaming, which makes it possible to be a functional food ingredient. More importantly, YSGH showed certain antioxidant activities and excellent ACE-inhibitory activities $\left(\mathrm{IC}_{50}=0.991 \mathrm{mg} / \mathrm{ml}\right)$. Therefore, the YSGH prepared in this study should be of potential utility as a bioactive ingredient in health food and pharmaceutical industries.

\section{Data Availability}

The data used to support the findings of this study are available from the corresponding author upon request.

\section{Conflicts of Interest}

The authors declare that there are no conflicts of interest regarding the publication of this paper.

\section{Acknowledgments}

This research was supported by the Key Technologies R\&D Program of Tianjin (Grant no. 14ZCZDNC00008) and the National Key Technology R\&D Program (Grant no. 2014BAD02B00). The authors are grateful to the State Key Laboratory of Chemical Engineering of Tianjin University for providing equipment and facilities.

\section{Supplementary Materials}

Supplementary Table S1: coded levels of the independent variables for fractional factorial designs used for yak skin gelatin hydrolysis. Table S2: program and results of the fractional factorial designs used for yak skin gelatin hydrolysis. Table S3: analysis of variance (ANOVA) for fractional factorial designs of DH. Table S4: regression equation for fractional factorial designs of DH. Table S5: levels of independent variables for DH (degree of hydrolysis) of yak skin gelatin hydrolysates and the results from response surface model. Table S6: analysis of variance (ANOVA) of developed quadratic polynomial model of DH. Table S7: emulsifying properties of yak skin gelatin hydrolysates. Table S8: foaming properties of yak skin gelatin hydrolysates. Figure S1: gel permeation chromatography of yak skin gelatin hydrolysis. (Supplementary Materials)

\section{References}

[1] K.-H. Leem, S. Lee, A. Jang, and H. K. Kim, "Porcine skin gelatin hydrolysate promotes longitudinal bone growth in adolescent rats," Journal of Medicinal Food, vol. 16, no. 5, pp. 447-453, 2013.

[2] Y. Zhang, K. Olsen, A. Grossi, and J. Otte, "Effect of pretreatment on enzymatic hydrolysis of bovine collagen and formation of ACE-inhibitory peptides," Food Chemistry, vol. 141, no. 3, pp. 2343-2354, 2013.

[3] M. Nikoo, S. Benjakul, and X. Xu, "Antioxidant and cryoprotective effects of amur sturgeon skin gelatin hydrolysate in unwashed fish mince," Food Chemistry, vol. 181, pp. 295-303, 2015.

[4] Y. Han, S.-H. Byun, J.-H. Park, and S.-B. Kim, "Bioactive properties of enzymatic hydrolysates from abdominal skin gelatin of yellowfin tuna (Thunnus albacares)," International Journal of Food Science \& Technology, vol. 50, no. 9, pp. 1996-2003, 2015.

[5] H. J. Zhu, S. P. Wang, L. Tian, and H. Zhang, "Production and purification of antioxidant peptides from flatfish skin protein hydrolysates," Transactions of Tianjin University, vol. 21, no. 5, pp. 433-439, 2015.

[6] D.-H. Ngo, K.-H. Kang, B. Ryu et al., "Angiotensin-i converting enzyme inhibitory peptides from antihypertensive skate (Okamejei kenojei) skin gelatin hydrolysate in spontaneously hypertensive rats," Food Chemistry, vol. 174, pp. 37-43, 2015.

[7] L. Tian, J. Liu, L. Ma et al., "Isolation and purification of antioxidant and ACE-inhibitory peptides from yak (Bos grunniens) skin," Journal of Food Processing and Preservation, vol. 41, no. 5, Article ID e13123, 2017.

[8] H. Cao, Y. Zhao, Y. B. Zhu, F. Xu, J. S. Yu, and M. Yuan, "Antifreeze and cryoprotective activities of ice-binding collagen peptides from pig skin," Food Chemistry, vol. 194, pp. 1245-1253, 2016.

[9] T. Chen, H. Hou, Y. Fan et al., "Protective effect of gelatin peptides from pacific cod skin against photoaging by inhibiting the expression of MMPs via MAPK signaling pathway," Journal of Photochemistry and Photobiology B: Biology, vol. 165, pp. 34-41, 2016.

[10] S. Anandhakumar, G. Krishnamoorthy, K. M. Ramkumar, and A. M. Raichur, "Preparation of collagen peptide functionalized chitosan nanoparticles by ionic gelation method: an effective carrier system for encapsulation and release of doxorubicin for cancer drug delivery," Materials Science and Engineering: C, vol. 70, no. 1, pp. 378-385, 2017.

[11] L. Fan, S. Zou, H. Ge et al., "Preparation and characterization of hydroxypropyl chitosan modified with collagen peptide," International Journal of Biological Macromolecules, vol. 93, pp. 636-643, 2016.

[12] E. Proksch, M. Schunck, V. Zague, D. Segger, J. Degwert, and S. Oesser, "Oral intake of specific bioactive collagen peptides reduces skin wrinkles and increases dermal matrix synthesis," Skin Pharmacology and Physiology, vol. 27, no. 3, pp. 113-119, 2014. 
[13] S. S. Li, Y. C. Jin, and Z. X. Yan, "Experiment of slaughtering Huan $\mathrm{Hu}$ yaks and meat quality investigation," Food Industry, vol. 27, pp. 172-174, 2016.

[14] C.-F. Chi, Z.-H. Cao, B. Wang, F.-Y. Hu, Z.-R. Li, and B. Zhang, "Antioxidant and functional properties of collagen hydrolysates from Spanish mackerel skin as influenced by average molecular weight," Molecules, vol. 19, no. 8, pp. 11211-11230, 2014.

[15] N. R. A. Halim, H. M. Yusof, and N. M. Sarbon, "Functional and bioactive properties of fish protein hydolysates and peptides: a comprehensive review," Trends in Food Science \& Technology, vol. 51, pp. 24-33, 2016.

[16] A. Lasekan, F. Abu Bakar, and D. Hashim, "Potential of chicken by-products as sources of useful biological resources," Waste Management, vol. 33, no. 3, pp. 552-565, 2013.

[17] O. Martínez-Alvarez, S. Chamorro, and A. Brenes, "Protein hydrolysates from animal processing by-products as a source of bioactive molecules with interest in animal feeding: a review," Food Research International, vol. 73, pp. 204-212, 2015.

[18] A. T. Alfaro, F. C. Biluca, C. Marquetti, I. B. Tonial, and N. E. de Souza, "African catfish (Clarias gariepinus) skin gelatin: extraction optimization and physical-chemical properties," Food Research International, vol. 65, pp. 416-422, 2014.

[19] C. Zhang, Y. Xing, and F. Hu, "Analysis and evaluation of amino acids and mineral composition in skin glue of yak," Modern Scientific Instruments, vol. 16, no. 3, pp. 50-51, 2006.

[20] P. Mokrejs, F. Langmaier, M. Mladek, D. Janacova, K. Kolomaznik, and V. Vasek, "Extraction of collagen and gelatine from meat industry by-products for food and non food uses," Waste Management \& Research, vol. 27, no. 1, pp. 31-37, 2009.

[21] J. Adler-Nissen, "Determination of the degree of hydrolysis of food protein hydrolysates by trinitrobenzenesulfonic acid," Journal of Agricultural and Food Chemistry, vol. 27, no. 6, pp. 1256-1262, 1979.

[22] Association of Offcial Analytical Chemists (AOAC), Official Methods of Analysis, AOAC, Washington, DC, USA, 13th edition, 1980.

[23] F. Shahidi, X. Q. Han, and J. Synowiecki, "Production and characteristics of protein hydrolysates from capelin (Mallotus villosus)," Food Chemistry, vol. 53, no. 95,3, pp. 285-293, 1995.

[24] R. A. Nazeer, N. S. Sampath Kumar, and R. Jai Ganesh, "In vitro and in vivo studies on the antioxidant activity of fish peptide isolated from the croaker (Otolithes ruber) muscle protein hydrolysate," Peptides, vol. 35, no. 2, pp. 261-268, 2012.

[25] Z. Xie, J. Huang, X. Xu, and Z. Jin, "Antioxidant activity of peptides isolated from alfalfa leaf protein hydrolysate," Food Chemistry, vol. 111, no. 2, pp. 370-376, 2008.

[26] I. G. J. D. Avellar, M. M. M. Magalhães, A. B. Silva et al., "Reevaluating the role of 1,10-phenanthroline in oxidative reactions involving ferrous ions and DNA damage," Biochimica Et Biophysica Acta General Subjects, vol. 1675, no. 1-3, pp. 46-53, 2004.

[27] D. W. Cushman and H. S. Cheung, "Spectrophotometric assay and properties of the angiotensin-converting enzyme of rabbit lung," Biochemical Pharmacology, vol. 20, no. 7, pp. 1637$1648,1971$.

[28] A. A. Karim and R. Bhat, "Fish gelatin: properties, challenges, and prospects as an alternative to mammalian gelatins," Food Hydrocolloids, vol. 23, no. 3, pp. 563-576, 2009.

[29] S. Mulyani, M. C. Francis, S. Setyabudi, Y. Pranoto, and U. Santoso, "Physicochemical properties of gelatin extracted from buffalo hide pretreated with different acids," Korean
Journal for Food Science of Animal Resources, vol. 37, no. 5, pp. 708-715, 2017.

[30] R.-H. Zhang, Z.-K. Liu, D.-S. Yang, X.-J. Zhang, H.-D. Sun, and W.-L. Xiao, "Phytochemistry and pharmacology of the genus Leonurus: the herb to benefit the mothers and more," Phytochemistry, vol. 147, pp. 167-183, 2018.

[31] F. LI, D. JIA, and K. YAO, "Amino acid composition and functional properties of collagen polypeptide from yak (Bos grunniens) bone," LWT-Food Science and Technology, vol. 42, no. 5, pp. 945-949, 2009.

[32] P. Thamnarathip, K. Jangchud, A. Jangchud, S. Nitisinprasert, S. Tadakittisarn, and B. Vardhanabhuti, "Extraction and characterisation of riceberry bran protein hydrolysate using enzymatic hydrolysis," International Journal of Food Science \& Technology, vol. 51, no. 1, pp. 194-202, 2016.

[33] H. Fan, M.-J. Dumont, and B. K. Simpson, "Extraction of gelatin from salmon (Salmo salar) fish skin using trypsinaided process: optimization by plackett-burman and response surface methodological approaches," Journal of Food Science and Technology, vol. 54, no. 12, pp. 4000-4008, 2017.

[34] J. Ao and B. Li, "Amino acid composition and antioxidant activities of hydrolysates and peptide fractions from porcine collagen," Food Science and Technology International, vol. 18, no. 5, pp. 425-434, 2012.

[35] T. L. Pownall, C. C. Udenigwe, and R. E. Aluko, "Amino acid composition and antioxidant properties of pea seed (Pisum sativum L.) enzymatic protein hydrolysate fractions," Journal of Agricultural and Food Chemistry, vol. 58, no. 8, pp. 47124718, 2010.

[36] C. C. Udenigwe and R. E. Aluko, "Chemometric analysis of the amino acid requirements of antioxidant food protein hydrolysates," International Journal of Molecular Sciences, vol. 12, no. 5, pp. 3148-3161, 2011.

[37] B. H. Sarmadi and A. Ismail, "Antioxidative peptides from food proteins: a review,” Peptides, vol. 31, no. 10, pp. 19491956, 2010.

[38] M. C. Gómez-Guillén, B. Giménez, M. E. López-Caballero, and M. P. Montero, "Functional and bioactive properties of collagen and gelatin from alternative sources: a review," Food Hydrocolls, vol. 25, no. 8, pp. 1813-1827, 2010.

[39] M. Wald, K. Schwarz, H. Rehbein et al., "Detection of antibacterial activity of an enzymatic hydrolysate generated by processing rainbow trout by-products with trout pepsin," Food Chemistry, vol. 205, pp. 221-228, 2016.

[40] R. Bermúdez, D. Franco, J. Carballo, M. Á. Sentandreu, and J. M. Lorenzo, "Influence of muscle type on the evolution of free amino acids and sarcoplasmic and myofibrillar proteins through the manufacturing process of CELTA dry-cured ham," Food Research International, vol. 56, no. 2, pp. 226-235, 2014.

[41] L. Wattanasiritham, C. Theerakulkait, S. Wickramasekara, C. S. Maier, and J. F. Stevens, "Isolation and identification of antioxidant peptides from enzymatically hydrolyzed rice bran protein," Food Chemistry, vol. 192, pp. 156-162, 2016.

[42] S. W. Lee, M. Shimizu, S. Kaminogawa, and K. Yamauchi, "Emulsifying properties of a mixture of peptides derived from the enzymatic hydrolyzates of bovine caseins," Journal of the Agricultural Chemical Society of Japan, vol. 51, no. 6, pp. 1535-1540, 2006.

[43] P. J. García-Moreno, R. Pérez-Gálvez, F. J. Espejo-Carpio et al., "Functional, bioactive and antigenicity properties of blue whiting protein hydrolysates: effect of enzymatic treatment and degree of hydrolysis," Journal of the Science of Food and Agriculture, vol. 97, no. 1, pp. 299-308, 2016. 
[44] M. Blanco, C. G. Sotelo, and R. I. Pérez-Martín, "Hydrolysis as a valorization strategy for unused marine food biomass: boarfish and small-spotted catshark discards and by-products," Journal of Food Biochemistry, vol. 39, no. 4, pp. 368-376, 2015.

[45] E. Dickinson, "Mixed proteinaceous emulsifiers: review of competitive protein adsorption and the relationship to food colloid stabilization," Food Hydrocolloids, vol. 1, no. 1, pp. 3-23, 1986.

[46] V. C. Van, H. Gruppen, D. B. de Bont, and A. G. Voragen, "Correlations between biochemical characteristics and foamforming and -stabilizing ability of whey and casein hydrolysates," Journal of Agricultural and Food Chemistry, vol. 50, no. 10, pp. 2938-2946, 2002.

[47] E. D. Cömert and V. Gökmen, "Evolution of food antioxidants as a core topic of food science for a century," Food Research International, vol. 105, pp. 76-93, 2018.

[48] N. Zhang, C. Zhang, Y. Chen, and B. Zheng, "Purification and characterization of antioxidant peptides of Pseudosciaena crocea protein hydrolysates," Molecules, vol. 22, no. 1, p. 57, 2016.

[49] Y. Zhang, W. Sun, M. Zhao, G. Su, Z. Ning, and D. SunWaterhouse, "Improvement of the ACE-inhibitory and DPPH radical scavenging activities of soya protein hydrolysates through pepsin pretreatment," International Journal of Food Science \& Technology, vol. 50, no. 10, pp. 2175-2182, 2015.

[50] S.-K. Kim, H.-G. Byun, P.-J. Park, and F. Shahidi, "Angiotensin I converting enzyme inhibitory peptides purified from bovine skin gelatin hydrolysate," Journal of Agricultural and Food Chemistry, vol. 49, no. 6, pp. 2992-2997, 2001. 


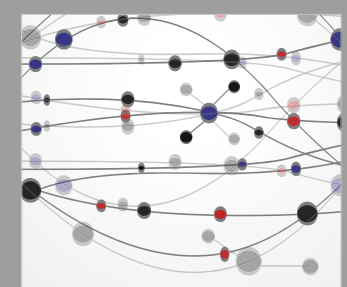

The Scientific World Journal
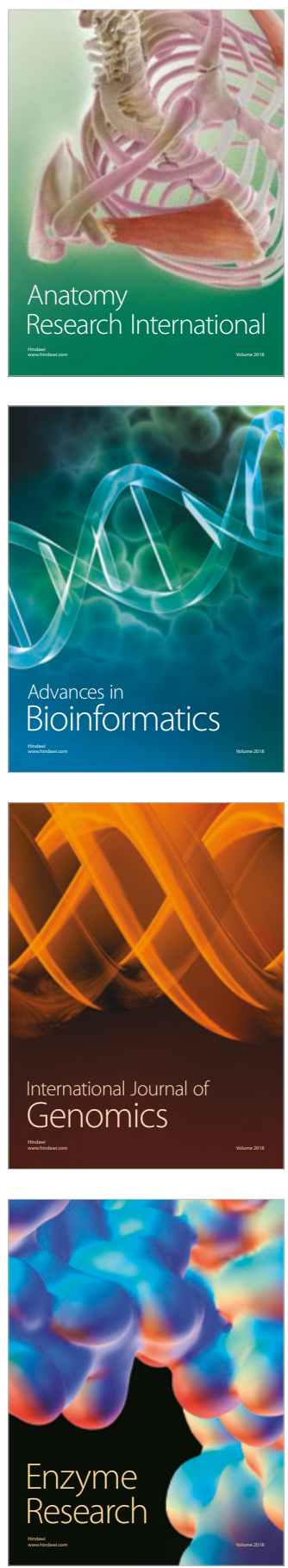
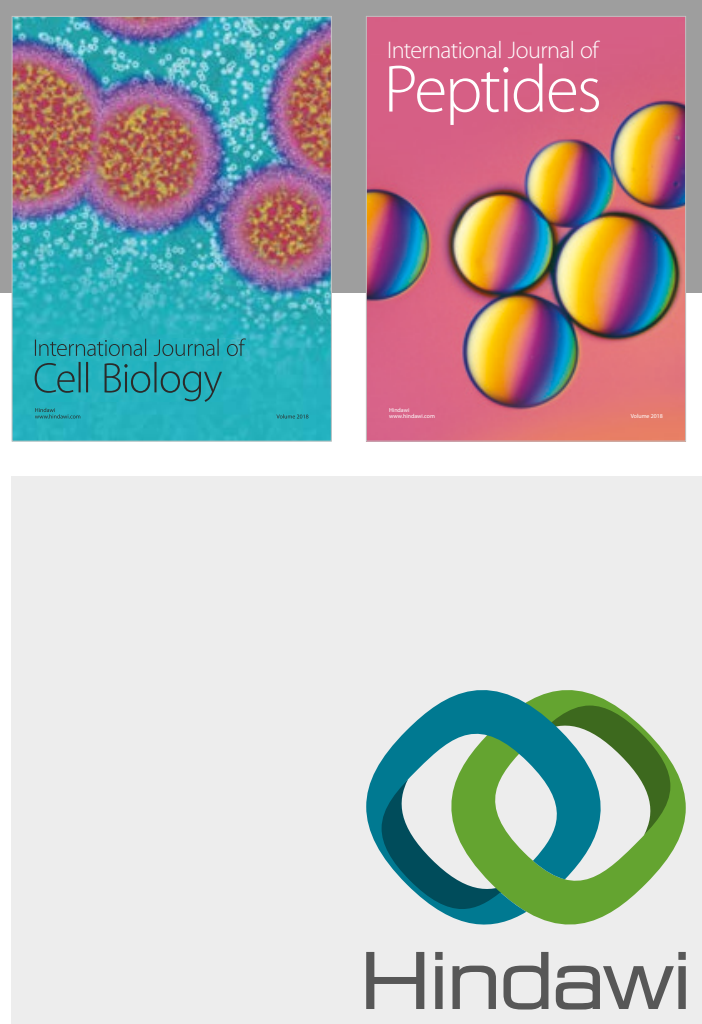

Submit your manuscripts at

www.hindawi.com
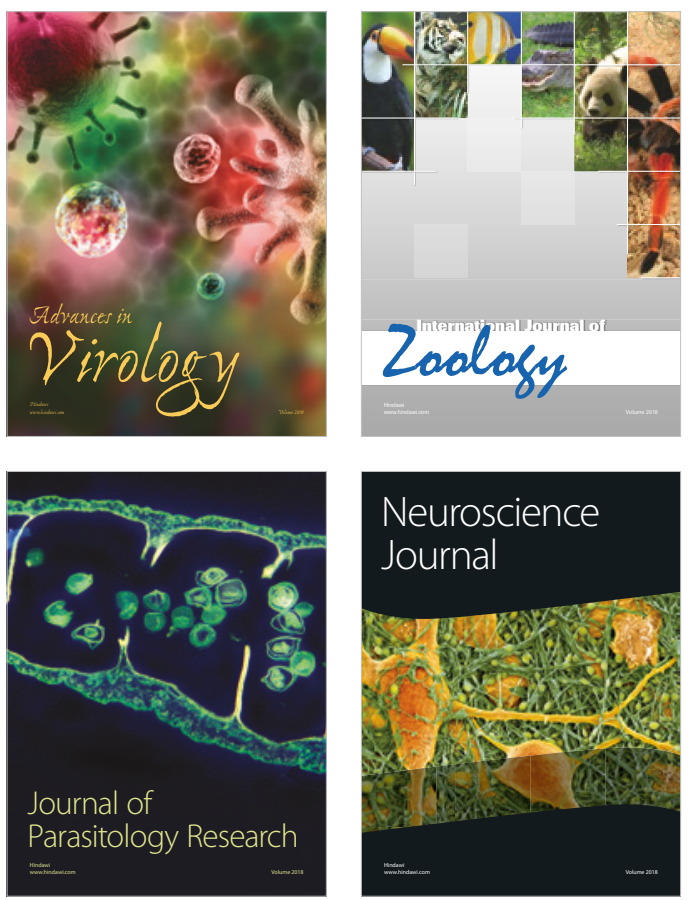
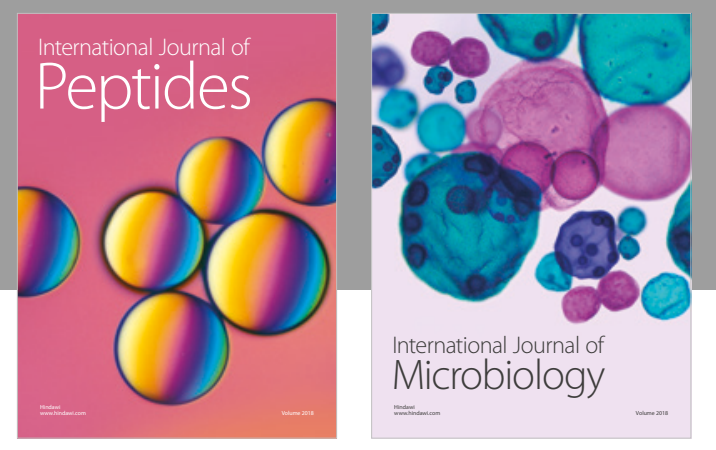

nternational Journal of Microbiology
Journal of
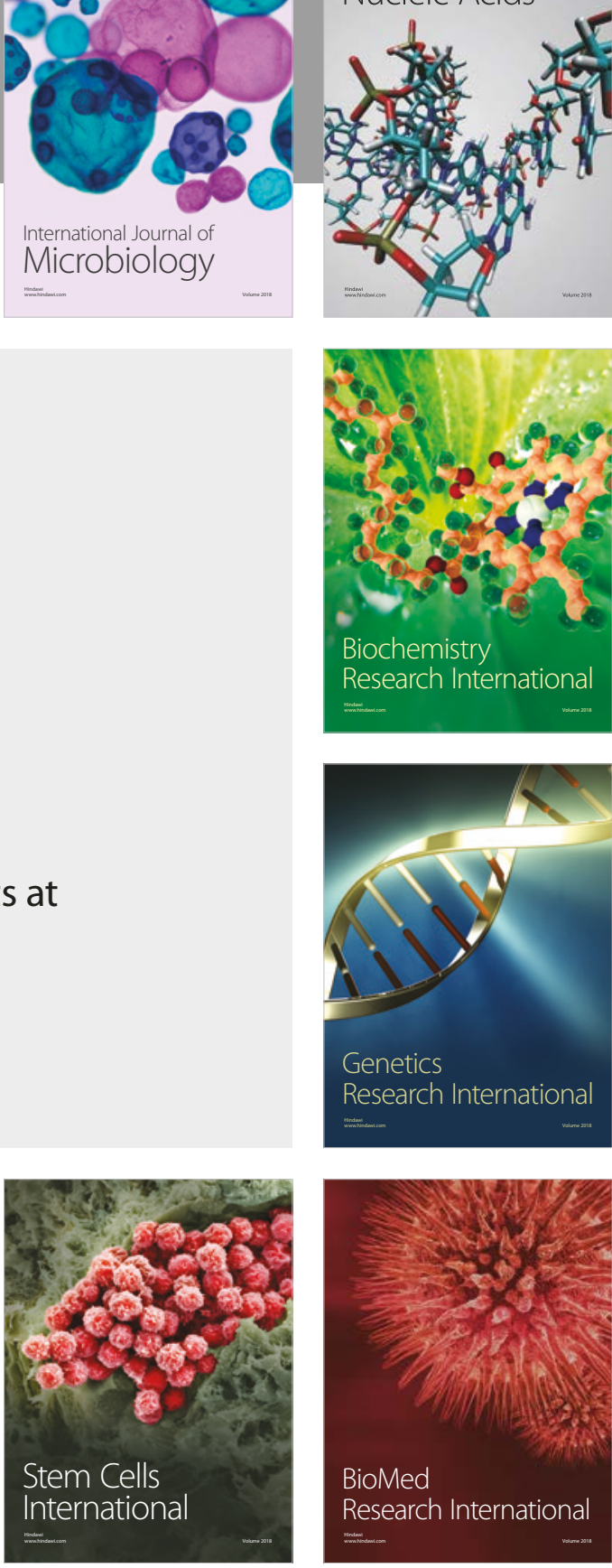
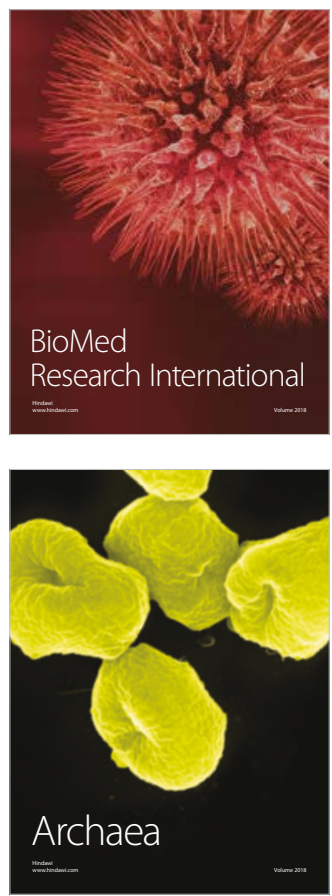